\title{
Effects of Tea (Camellia sinensis) Phytochemicals on the Yoghurt Cultures (Lactobacillus bulgaricus and Streptococcus thermophilus) During Development and Storage of Tea Fortified Yoghurts
}

\author{
Simon Oduor Ochanda ${ }^{1}$, John Kanyiri Wanyoko ${ }^{1}$, Abdul Kiptoo Faraj ${ }^{2}$, Christine Akoth Onyango $^{3}$ \& \\ Henrik Kipngeno Ruto ${ }^{1}$ \\ ${ }^{1}$ Kenya Agricultural and Livestock Research Organization, Tea Research Institute, Kenya \\ ${ }^{2}$ Egerton University, Kenya \\ ${ }^{3}$ Taita Taveta University College, Kenya \\ Correspondence: Henrik Kipngeno Ruto, Kenya Agricultural and Livestock Research Organization, Tea \\ Research Institute, Kenya. P.O Box 820-20200, Kericho, Kenya. Tel: 254-724-363-181. E-mail: \\ rutohenrik@yahoo.com
}

Received: March 23, 2015 Accepted: May 27, 2015 Online Published: June 2, 2015

doi:10.5539/jfr.v4n4p59 URL: http://dx.doi.org/10.5539/jfr.v4n4p59

\begin{abstract}
Tea phytochemicals have been reported to exhibit potent antimicrobial activity. This current study reports the ability of Streptococcus thermophilus and Lactobacillus bulgaricus to grow, survive and multiply in the presence of tea phytochemicals during development and storage of tea fortified yoghurts. Two Kenyan tea varieties clone TRFK 6/8 (standard black quality tea) and clone TRFK 306/1 (newly developed purple leafed tea clone), were processed as aerated and non-aerated teas and used to develop tea fortified yoghurt. The teas were added at concentrations of $0,1,2$ and $4 \mathrm{~g}$ in $250 \mathrm{~mL}$ volumes of milk (w/v) which was predetermined by sensory tests. The results showed that tea phytochemicals at the added ranges had no adverse effect on the growth of Lactobacillus bulgaricus and Streptococcus thermophilus; however, yoghurt setting time was prolonged at a mean time of 4.11, 5.22, 7.29 and $8.26 \mathrm{hrs}$ respectively for tea concentrations of $0,1,2$ and $4 \mathrm{~g} / 250 \mathrm{~mL} \mathrm{milk}$. The mean microbial load for Lactobacillus bulgaricus and Streptococcus thermophilus in black, green and purple tea yoghurts were also inversely proportional to the concentration of the added teas. In the developmental stages of tea fortified yoghurts Lactobacillus bulgaricus range was $0.52-1.58 \times 10^{7} \mathrm{CFU} / \mathrm{mL}$ while Streptococcus thermophilus range was $2.53-3.51 \times 10^{9} \mathrm{CFU} / \mathrm{mL}$, during storage the growth patterns were different between the cultures. The recorded mean values range for Lactobacillus bulgaricus was $2.79-4.35 \times 10^{7} \mathrm{CFU} / \mathrm{mL}$ while Streptococcus thermophilus mean range was 2.57-3.47 $\times 10^{9} \mathrm{CFU} / \mathrm{mL}$ Phytochemicals traced in the product had concentration values below $5 \times 10^{2} \mathrm{\mu gmL}^{-1}$. In conclusion, it was possible to develop probiotic tea fortified yoghurt containing tea phytochemicals with unlimited health benefits using different the different tea clones.
\end{abstract}

Keywords: tea phytochemicals, starter culture, microbial range, incubation, setting time, shelf life

\section{Introduction}

Kenya is a tea growing country and produces black tea as its major trading product commodity. In addition only $5 \%$ of this is consumed within the country while the remaining $95 \%$ is exported (Ochanda, 2010). In recent years, black tea prices have been on the decline while other speciality teas and tea products have been on the rise. In order to address this issue and turn around the tea industry product diversification and value addition is required as is done in developed countries (Ochanda, 2010; Lelgo, Kamunya, Ochanda, \& Wanyoko, 2011; Trienekens, 2011). Tea is usually used to fortify various foods due to its low pH (4.2) (Yilmaz, 2006), high polyphenol, antioxidant and potent antimicrobial activity (Almajano, Carbó, Jiménez, \& Gordon, 2008; Jaziri, Slama, Mhadhbi, Gannoun, \& Othman, 2005; Koech et al., 2013; Oh, Jo, Cho, Kim, \& Han, 2013). This research focused on value addition of tea through the development of tea fortified yoghurts. The tea fortified yoghurts was intended to have double health benefits including the yoghurt starter cultures' probiotic properties and tea phytochemicals both of which are associated with unlimited health benefits. However there was a possible challenge, in the development and production of the tea fortified yoghurt with regard to the growth and survival of the yoghurt cultures owing to teas inherent antimicrobial activity. 


\subsection{Yoghurt}

Yoghurt is a dairy product obtained by lactic acid fermentation of milk by Lactobacillus delbrueckii ssp. Bulgaricus and Streptococcus thermophilus which acidify milk and synthesize aromatic compounds (Jaziri et al., 2005; Serra, Trujillo, Guamis, \& Ferragut, 2009). It contains viable micro flora of starter origin at the time of consumption, with minimum values between $10^{6}$ and $10^{8} \mathrm{CFU} / \mathrm{mL}$ (Serra et al., 2009; Lourens-Hattingh \& Viljoen, 2001). The lactose in the milk is converted to lactic acid when fermented. Lactic acid acts on the protein in the milk to give yoghurt its texture and characteristic tang (Rao, Tanksale, Ghatge, \& Deshpande, 1998). The milk is usually heat treated to pasteurization temperatures and time to kill all pathogenic and some spoilage microorganisms and to change the physical structure of the milk proteins so that they set together instead of forming curds. Afterwards it is cooled to $45^{\circ} \mathrm{C}$, the starter culture bacteria are then added and the milk is incubated at that temperature for approximately $4-4.5 \mathrm{hr}$ to ferment. The product exists in a variety of forms i.e. stirred, set, frozen and liquid yoghurt. Good packaging is essential for preservation of the product (Marth \& Steele, 2001). Yoghurt is rich in the macronutrient protein, and other micronutrients namely calcium, riboflavin, vitamin B6 and vitamin B12 (Campbell, 2003). Moderately lactose-intolerant people can consume yoghurt without ill effects. It prevents antibiotic-associated diarrhea, promotes good gum health and low-fat yoghurt promotes weight loss (Jaziri et al., 2005). Nutraceuticals such as high fiber, low fat yoghurt also exist (Jaziri, Slama, Mhadhbi, Urdaci, \& Hamdi, 2009). Food consumers the world over are showing increasing interest in such health-promoting foods in the diet (Varga, 2006).

\subsection{Tea and Tea Products}

The tea plant Camellia sinensis leaves have traditionally been processed into aerated, semi-aerated and non-aerated teas (Wilson \& Clifford, 1991). There are different tea varieties with different biochemical properties which are cultivated in various parts of the world. Agronomic practices and geographic regions, climatic conditions and seasons affects the tea phytochemicals (Cheruiyot, Mumera, Ng'etich, Hassanali, \& Wachira, 2007; Y Hara, Luo, \& Wickremashinghe, R L Yamanishi, 1995; Kerio, Wachira, Wanyoko, \& Rotich, 2013; Kilel, Faraj, Wanyoko, Wachira, \& Mwingirwa, 2013; Mukhtar \& Ahmad, 2000; Prior \& Wu, 2006; Wilson \& Clifford, 1991). The different processing methods modify the tea phytochemicals into various compounds hence different tastes and biochemical properties of teas. However with the advent of value addition other products such as tea extracts instant teas, iced teas, and tea fortified foods have been developed ( Balentine, 1997; Karori, Wachira, Wanyoko, \& Ngure, 2007; Lelgo et al., 2011; Ochanda 2010;Robertson, 1992).

\subsection{Antimicrobial Activity of Tea Extracts}

The antimicrobial activity of tea against some bacteria and fungi has been demonstrated by several researchers (Arakawa, Maeda, Okubo, \& Shimamura, 2004; Goto et al., 1998; Hamilton-Miller \& Shah, 1999; Hamilton-Miller, 1997, 2001; Ikigai, Nakae, Hara, \& Shimamura, 1993; Koech \& Wachira, 2013; Navarro-Martínez et al., 2005; Stapleton, Shah, Anderson, et al., 2004; Stapleton, Shah, Hamilton-Miller, et al., 2004; Zhang \& Rock, 2004). Depending on the type of processing, different tea have different active compounds responsible for these microbial activities. The major active compound for these direct antimicrobial effects in non-aerated green tea and its extracts appears to be the tea phytochemicals Epigallocatechin gallate (EGCG). In black tea and black tea extracts, the active biomolecule which is thought to be responsible for the antibacterial activity is the catechin dimer theaflavin (TF) and its gallate while in purple tea it is the anthocyanins in general (Cisowska, Wojnicz, \& Hendrich, 2011). The commercially available green tea extracts have been formulated and incorporated as active ingredients in various products such as antiseptic creams, mouthwashes, hand washes, facemasks among other products in order to prevent infections (Ochanda, 2010). Tea extracts have also been introduced into vacuum cleaner filters in order to reduce airborne contamination with microorganisms (Yukihiko Hara, 2001). Products having catechin-mediated photo-protection effects of human skin against bacterial infection has also been claimed (Hsu, 2005) and some researchers have found that topical tea ointment was as effective for the treatment of impetigo as a topical antibiotic mixture (framycetin and gramicidin) or an oral cephalexin (Sharquie, Al-Turfi, \& Al-Salloum, 2000).

Activity against various other microbial pathogens or factors involved in th5eir virulence has been shown; these include viruses such as hepatitis, HIV (Fassina et al., 2002), rotavirus, enterovirus and influenza virus (Song, Lee, \& Seong, 2005), yeasts (Hirasawa \& Takada, 2004), filamentous fungi (Okubo, Toda, Hara, \& Shimamura, 1991), chlamydia, mycoplasmas (Chosa, Toda, Okubo, Hara, \& Shimamura, 1992) and parasites (Paveto et al., 2004).

Due to the antimicrobial activity associated with tea components, an assay on the effect of incorporating tea in yoghurt was investigated, by looking into the interaction of tea phytochemicals with yoghurt starter culture 
during the development and storage of the tea fortified yoghurts.

\section{Methods}

The experiment was a $3 \times 4$ factorial embedded on a Randomized Complete Block Design (RCBD) consisting of yoghurts fortified with black, green and purple tea at 4 varying concentrations of $0,1,2$, and $4 \mathrm{~g} / 250 \mathrm{~mL}(\mathrm{w} / \mathrm{v})$. The control yoghurt had all the ingredients used to prepare the yoghurts except the teas

\subsection{Processing of Aerated and Non Aerated Teas}

Aerated teas were withered, macerated, oxidized and dried according to the method by (Kilel et al., 2013). Non-aerated teas were, blanched, withered, macerated and dried according to the method by (Ochanda, Wanyoko, Onyango, Faraj \& Kamunya, 2012).

\subsection{Processing of Tea Fortified Yoghurts}

\subsubsection{Materials for Yoghurt Processing}

The ingredients included; Teas (aerated and non-aerated teas from two Kenyan tea varieties Clone TRFK 6/8, Purple tea clone TRFK 306/1) obtained from Tea Research Institute, sugar, whole milk, yoghurt starter culture (Mixture of L. bulgaricus and S. thermophilus), skimmed milk powder, packaging material (plastic bottles).

\subsubsection{Development and Storage of Yoghurts}

Fresh milk was homogenized, fortified with the teas at rates of $1 \mathrm{~g}, 2 \mathrm{~g}$ and $4 \mathrm{~g} / 250 \mathrm{~mL}(\mathrm{w} / \mathrm{v})$ and then pasteurized to produce black, green and purple tea fortified yoghurts. Each set of yoghurt had a control without tea. The milk was infused in the teas then pasteurized by boiling at $90{ }^{\circ} \mathrm{C}$ for $3 \mathrm{~min}$, filtered, cooled to $45^{\circ} \mathrm{C}$ and inoculated with $6.5 \%(\mathrm{w} / \mathrm{v})$ lactic starter culture at a ratio of 2:1 Streptococcus salivarius ssp. thermophilus and L. delbrueckii ssp. bulgaricus. Incubation was done for $4-8 \mathrm{hrs}$ at $45^{\circ} \mathrm{C}$ (optimum temperature) which brought the $\mathrm{pH}$ of the yoghurts to between 4.5-4.6. Yoghurts were cooled and stored at $4{ }^{\circ} \mathrm{C}$. The viscosity and $\mathrm{pH}$ of the yoghurts were monitored from inoculation to the setting stage of the products. Enumeration of starter culture microorganisms of yoghurts during post-acidification period was also carried out weekly for 63 days to determine the interaction between tea and yoghurt cultures.

\subsection{Determination and Measurement of Yoghurt Setting Time}

The setting of the tea fortified yoghurts and their controls was determined by $\mathrm{pH}$ Meter assays during development at values between $\mathrm{pH}$ 4.5-4.6 which was determined according to AOAC method (AOAC, 2012).

\subsection{Enumeration of Yoghurts Microbial Starter Culture}

Aseptic sampling was done and samples diluted 9 times. One (1) $\mathrm{mL}$ of diluted sample was transferred into $9 \mathrm{~mL}$ of sterile peptone water. Further dilutions were appropriately made as required. The standard spread plate method was used to determine the viable cell counts of starter organisms (AOAC, 2012). M17 agar at pH $7.1 \pm$ 0.1 was used to culture $S$. thermophilus, incubated at $45^{\circ} \mathrm{C}$ for $48 \mathrm{hr}$ under aerobic conditions before enumeration. $S$. thermophilus formed lenticular colonies. Colony forming units (CFU) enumerated were expressed per milliliter $(\mathrm{mL})$ of yoghurt sample, and used to report survival of streptococci. Acidified MRS agar at $\mathrm{pH} 6.5$ was used for the culture of L. bulgaricus, incubated at $45^{\circ} \mathrm{C}$ for $48 \mathrm{hr}$ under aerobic conditions. L. bulgaricus formed 1-3 mm diameter colonies. The counts were expressed as colony forming units (CFU) per $\mathrm{mL}$ of sample.

\subsection{Statistical Analysis}

Analysis of variance (ANOVA) and mean comparisons of yoghurt setting time and of surviving starter cultures of S. thermophilus and L. bulgaricus during product development and storage was determined at $\mathrm{P} \leq 0.05$ with the system programme SAS (Arthur, 2013).

\section{Results}

Tea fortified yoghurt cultures, Lactobacillus delbrueckii ssp. bulgaricus and Streptococcus salivarius ssp. thermophilus are displayed in Figure 1. The cultures survived the added tea phytochemicals from the black, green and purple teas during yoghurt development. 


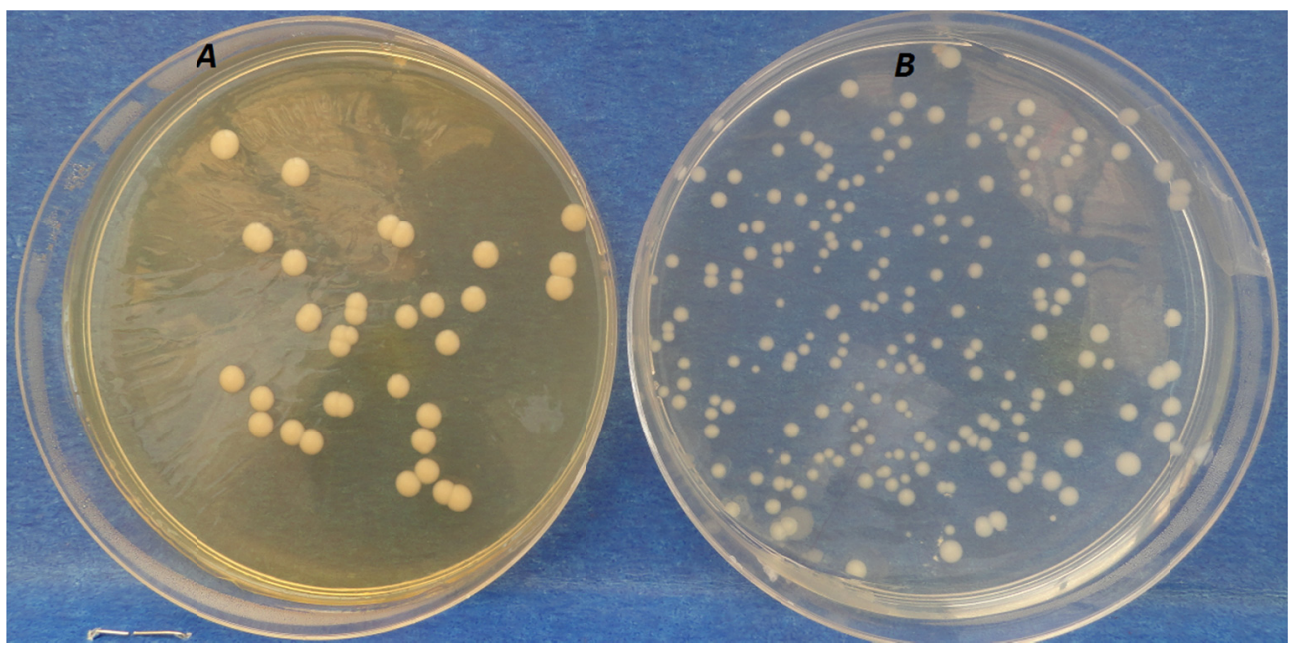

Figure 1. Bacterial colony forming units of (A) Lactobacillus delbrueckii ssp. bulgaricus and (B) Streptococcus salivarius ssp. thermophilus on MRS and M17 agar respectively

\subsection{Tea Fortified Yoghurt Setting Time}

Table 1 shows the setting time of the various tea fortified yoghurts developed. Black tea fortified yoghurt setting times were $4.11,5.10,7.10$ and $8.10 \mathrm{hr}$ respectively for tea concentrations of $0,1,2$ and $4 \mathrm{~g} / 250 \mathrm{~mL}$, green tea yoghurt setting time were $4.11,5.10,7.30$ and $8.33 \mathrm{hr}$ respectively for tea concentrations of $0,1,2$ and $4 \mathrm{~g} / 250$ $\mathrm{mL}$. While purple tea yoghurts setting time were $4.11,5.47,7.47$ and $8.33 \mathrm{hr}$ respectively for tea concentrations of $0,1,2$ and $4 \mathrm{~g} / 250 \mathrm{~mL}$ (Iwalokun \& Shittu, 2007).

Table 1. Black, green and purple tea fortified yoghurt setting time

\begin{tabular}{lllll}
\hline Tea & \multicolumn{4}{l}{ Tea fortified yoghurt setting time in hours } \\
\cline { 2 - 5 } Conc. & Black tea & Green tea & Purple tea & Mean \\
\hline $0 \mathrm{~g}$ & $4.11^{\mathrm{d}} \pm 0.09$ & $4.11^{\mathrm{d}} \pm 0.09$ & $4.11^{\mathrm{d}} \pm 0.09$ & $4.11^{\mathrm{d}}$ \\
$1 \mathrm{~g}$ & $5.10^{\mathrm{c}} \pm 0.10$ & $5.10^{\mathrm{c}} \pm 0.10$ & $5.47^{\mathrm{c}} \pm 0.06$ & $5.22^{\mathrm{c}}$ \\
$2 \mathrm{~g}$ & $7.10^{\mathrm{b}} \pm 0.10$ & $7.30^{\mathrm{b}} \pm 0.17$ & $7.47^{\mathrm{b}} \pm 0.06$ & $7.29^{\mathrm{b}}$ \\
$4 \mathrm{~g}$ & $8.10^{\mathrm{a}} \pm 0.10$ & $8.33^{\mathrm{a}} \pm 0.15$ & $8.33^{\mathrm{a}} \pm 0.29$ & $8.26^{\mathrm{a}}$ \\
Mean & 6.1 & 6.21 & 6.34 & 6.22 \\
LSD & 0.14 & 0.22 & 0.29 & 0.14 \\
CV & 1.15 & 1.73 & 2.32 & 2.31 \\
\hline
\end{tabular}

Value $=$ Mean \pm S.D on dry weight basis. Each value is a mean of 3 replicates. Means of the same parameter followed by the same letter are not significantly different $(\mathrm{P} \leq 0.05)$. S.D $=$ Standard deviation. $\mathrm{LSD}=$ Least significant difference $(\mathrm{P} \leq 0.05)$. $\mathrm{CV}=$ Coefficient of variation $(\%)$. Setting time values are in hours. 

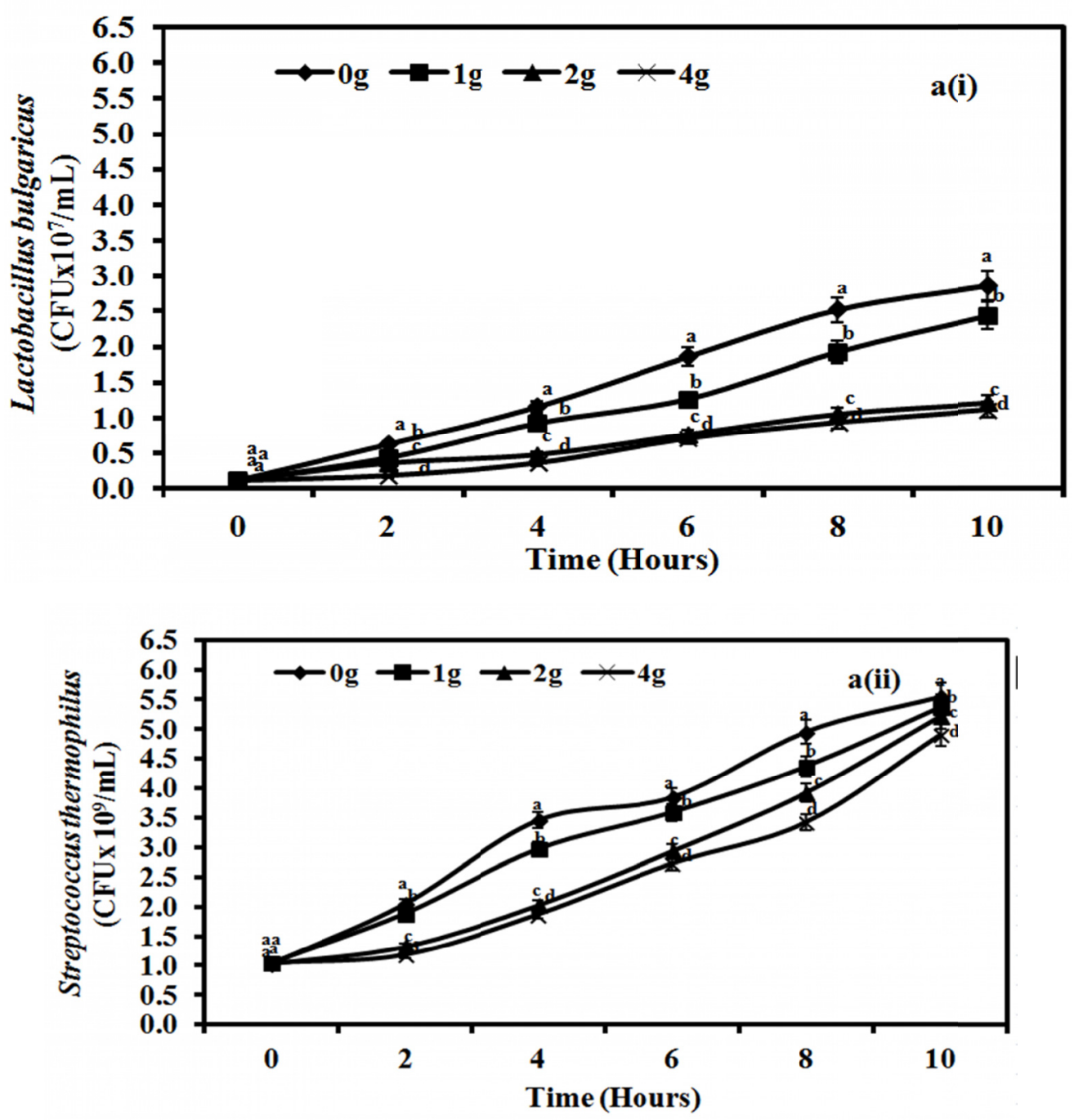

Figure 2a. (i) Lactobacillus bulgaricus (CFU $\left.\times 10^{7} / \mathrm{mL}\right)$ and (ii) Streptococcus thermophilus $\left(\mathrm{CFU} \times 10^{9} / \mathrm{mL}\right)$ in Black tea fortified yoghurts. Values are Means of three replicates in $1 \mathrm{~mL}$ of sample

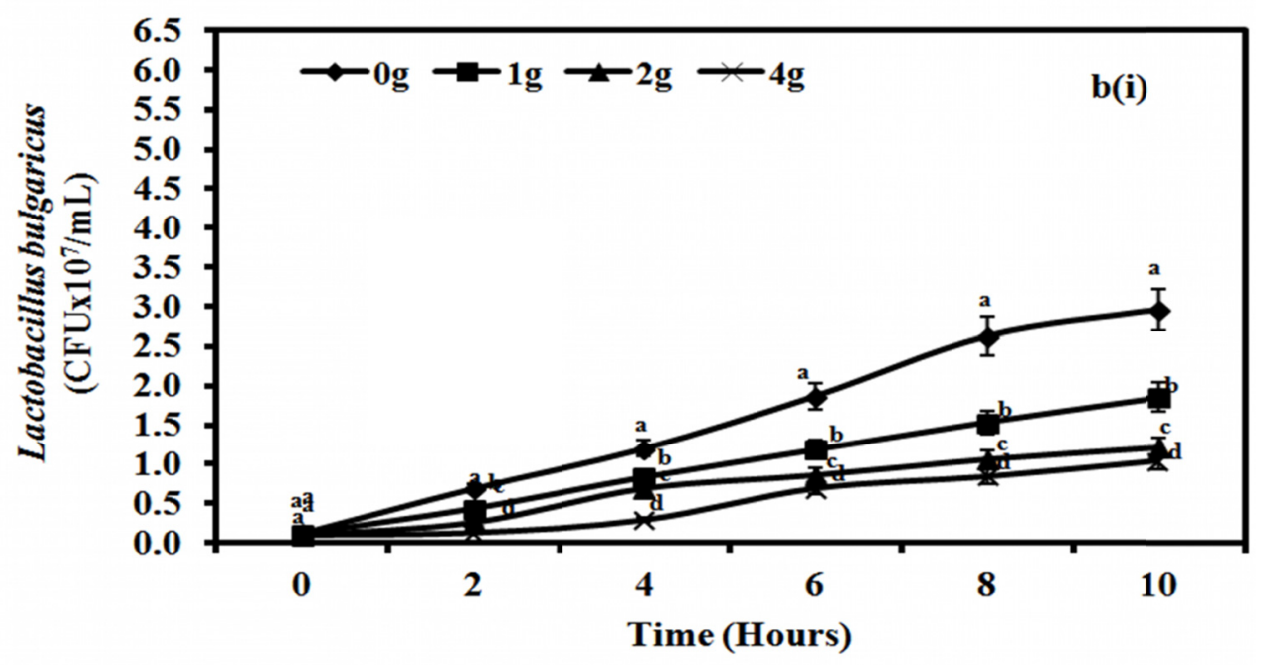




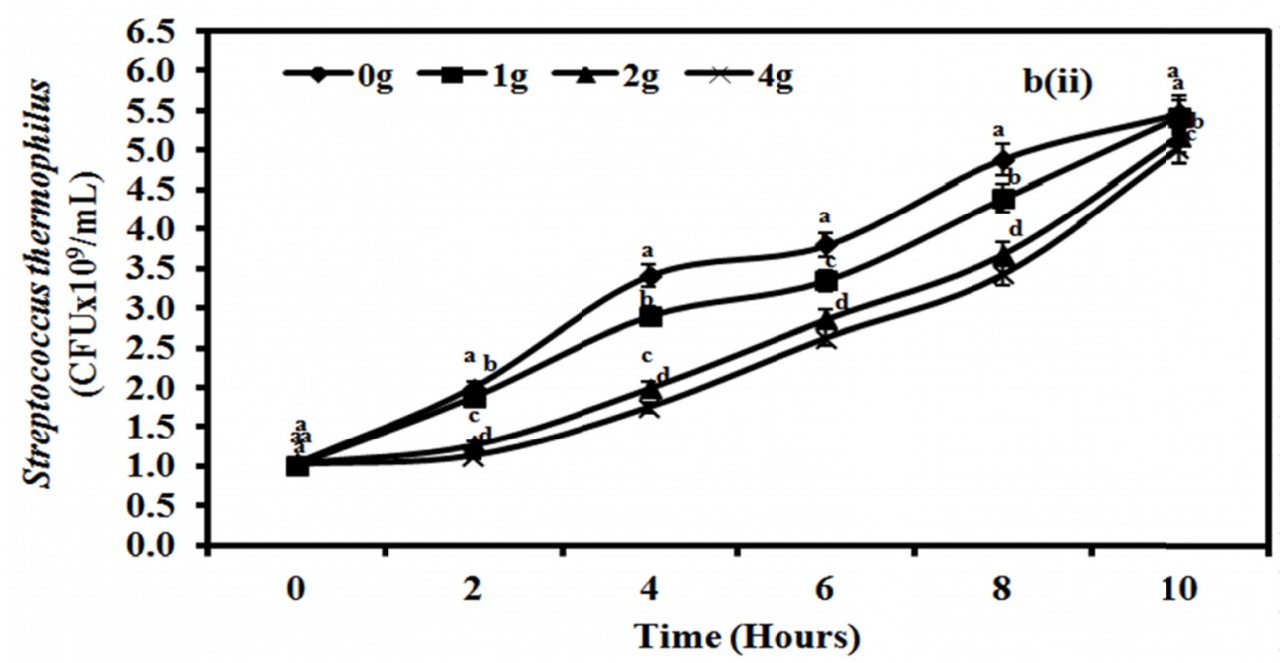

Figure 2b. (i) Lactobacillus bulgaricus $\left(\mathrm{CFU} \times 10^{7} / \mathrm{mL}\right)$ and (ii) Streptococcus thermophilus $\left(\mathrm{CFU} \times 10^{9} / \mathrm{mL}\right)$ in Green tea fortified yoghurts. Values are Means of three replicates in $1 \mathrm{~mL}$ of sample
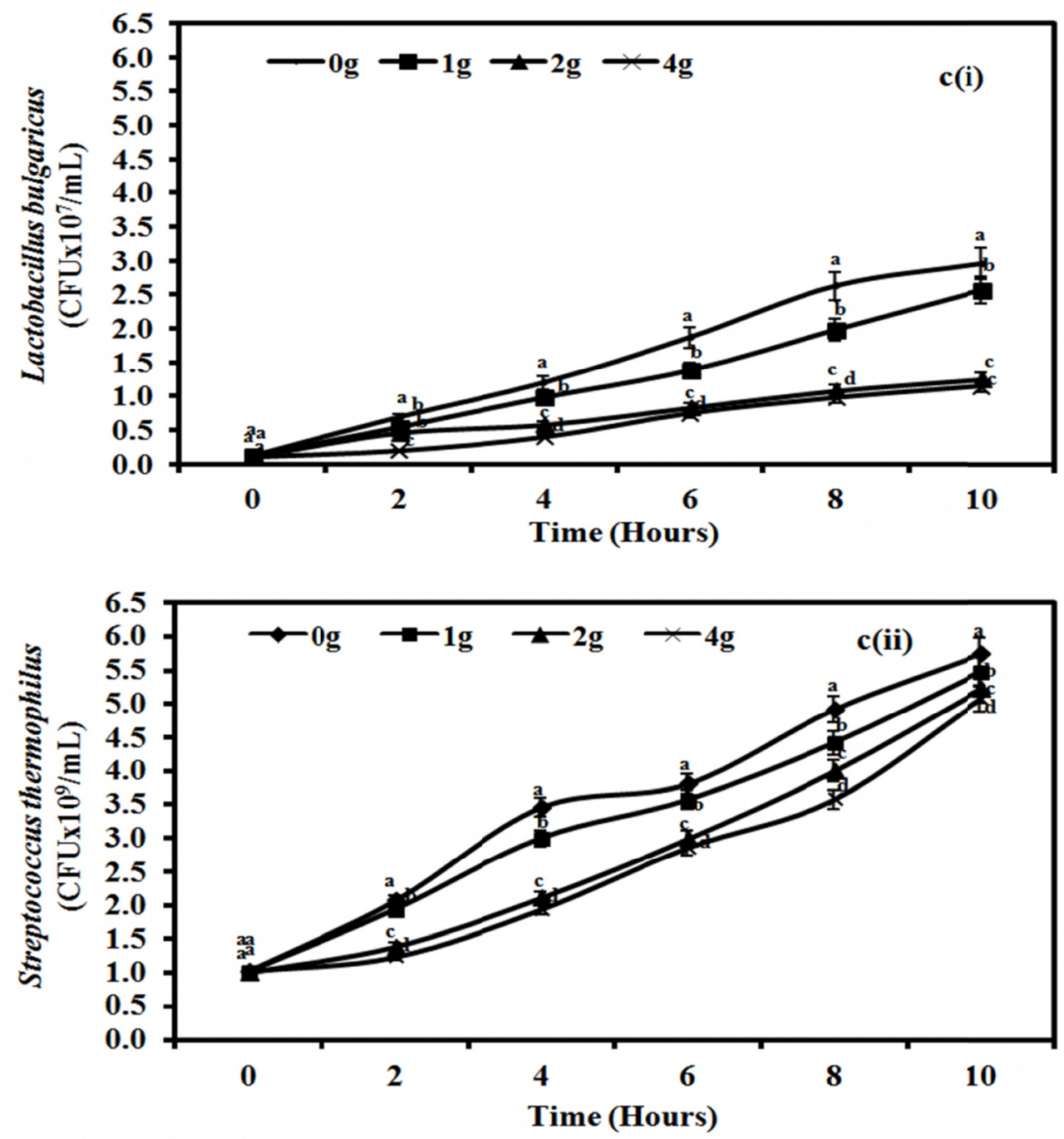

Figure 2c. (i) Lactobacillus bulgaricus $\left(\mathrm{CFU} \times 10^{7} \mathrm{~mL}\right)$ and (ii) Streptococcus thermophilus $\left(\mathrm{CFU} \times 10^{9} / \mathrm{mL}\right)$ in Purple tea fortified yoghurts. Values are Means of three replicates in $1 \mathrm{~mL}$ of sample 

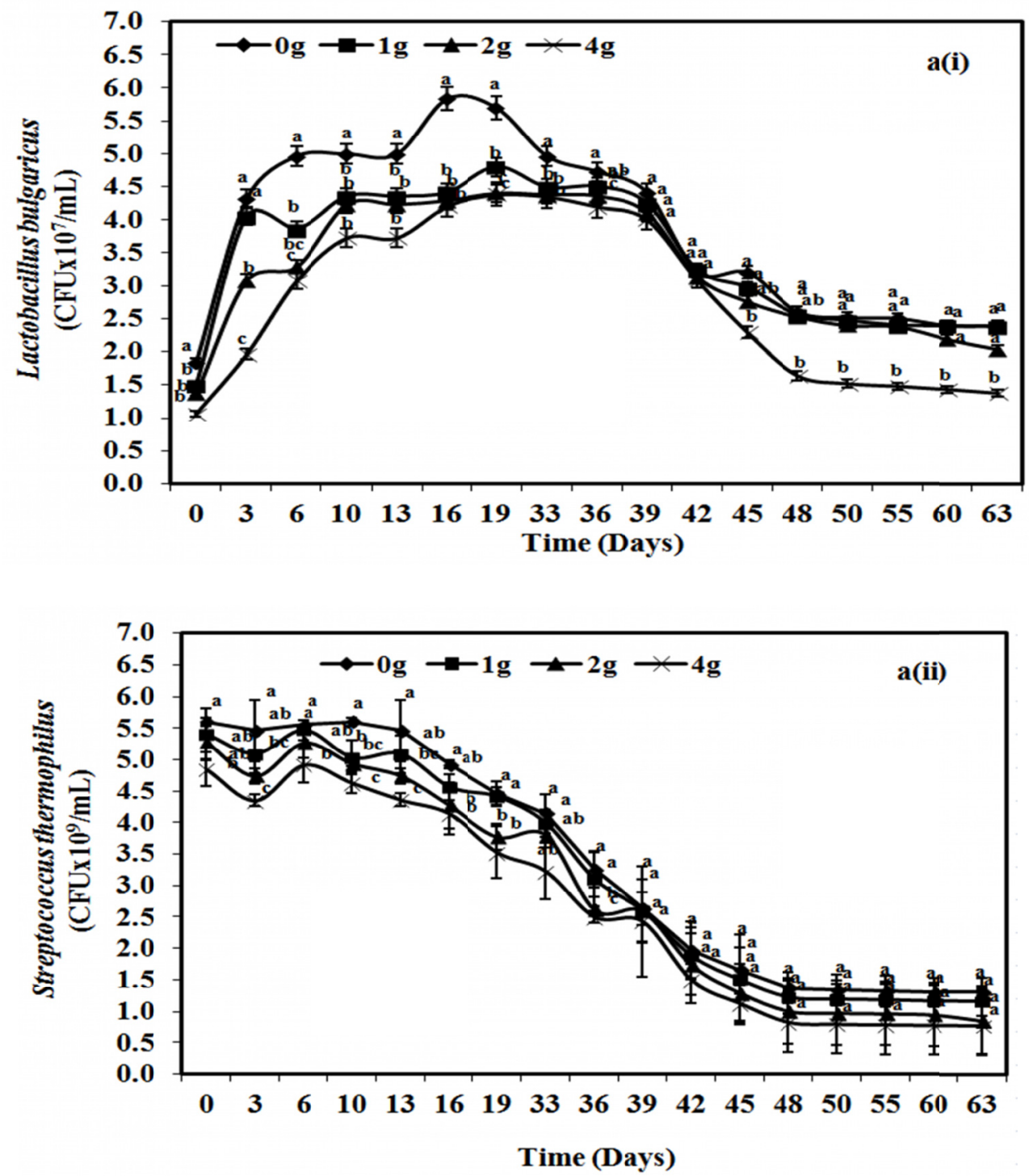

Figure 3a. (i) Lactobacillus bulgaricus $\left(\mathrm{CFU} \times 10^{7} / \mathrm{mL}\right)$ and (ii) Streptococcus thermophilus $\left(\mathrm{CFU} \times 10^{9} / \mathrm{mL}\right)$ in Black tea fortified yoghurts. Values are Means of three replicates in $1 \mathrm{~mL}$ of sample

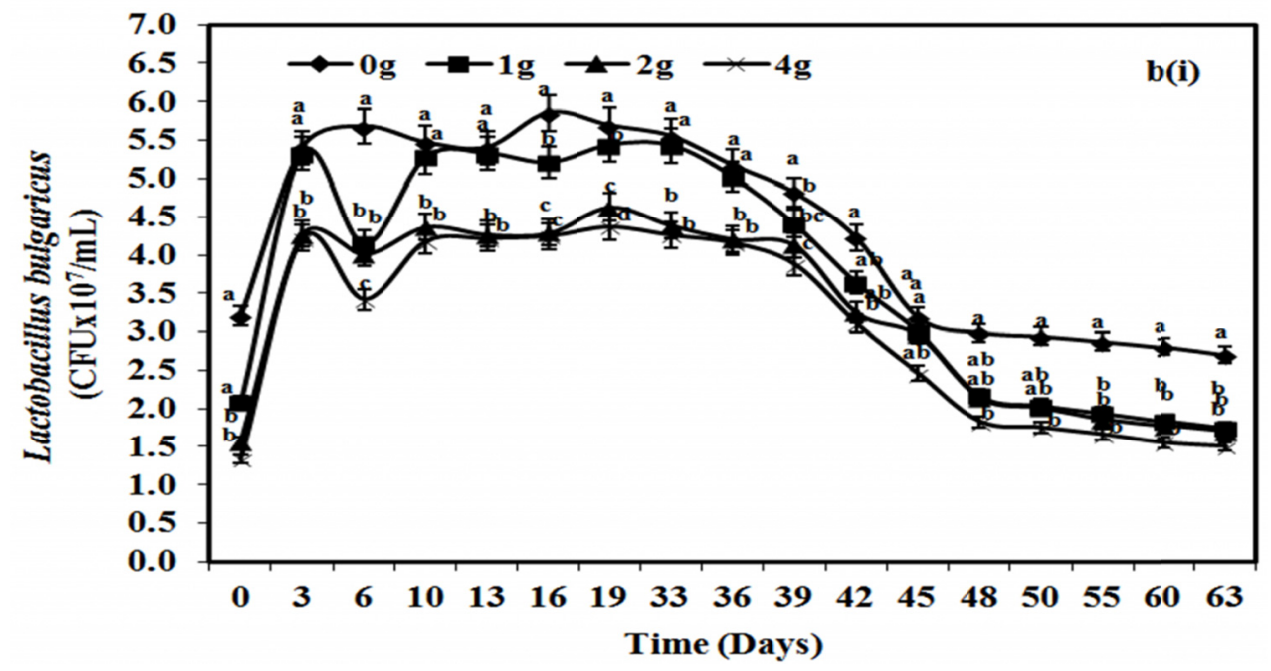




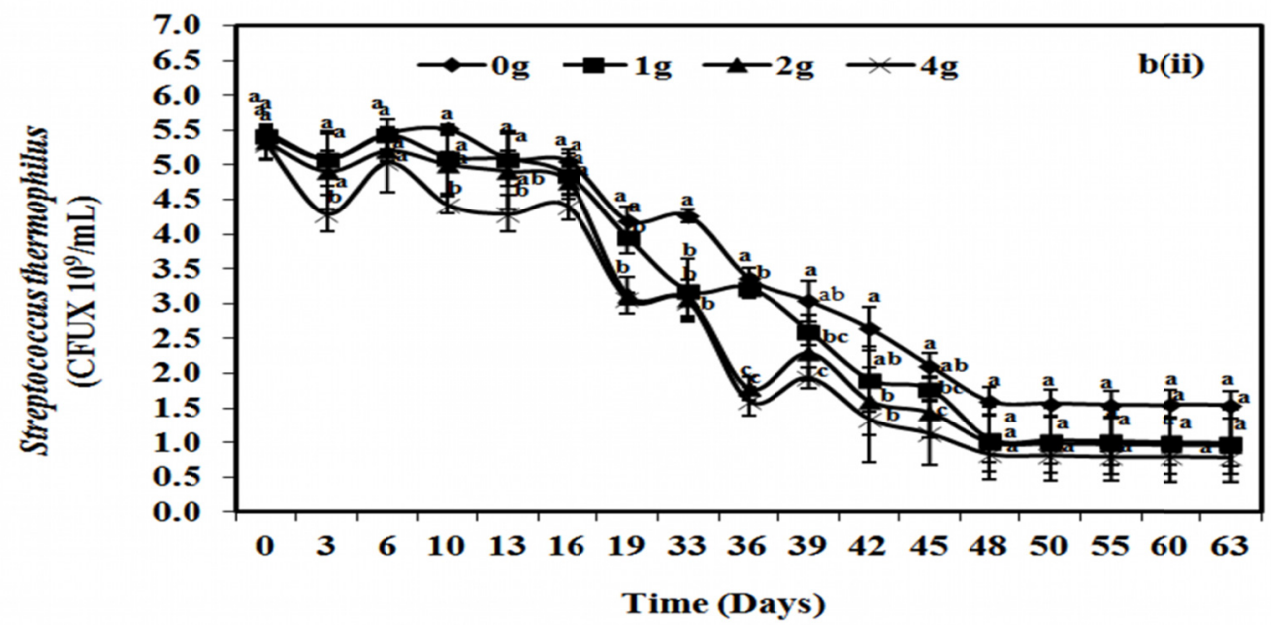

Figure 3b. (i) Lactobacillus bulgaricus $\left(\mathrm{CFU} \times 10^{7} / \mathrm{mL}\right)$ and (ii) Streptococcus thermophilus $\left(\mathrm{CFU} \times 10^{9} / \mathrm{mL}\right)$ in Green tea fortified yoghurts. Values are Means of three replicates in $1 \mathrm{~mL}$ of sample
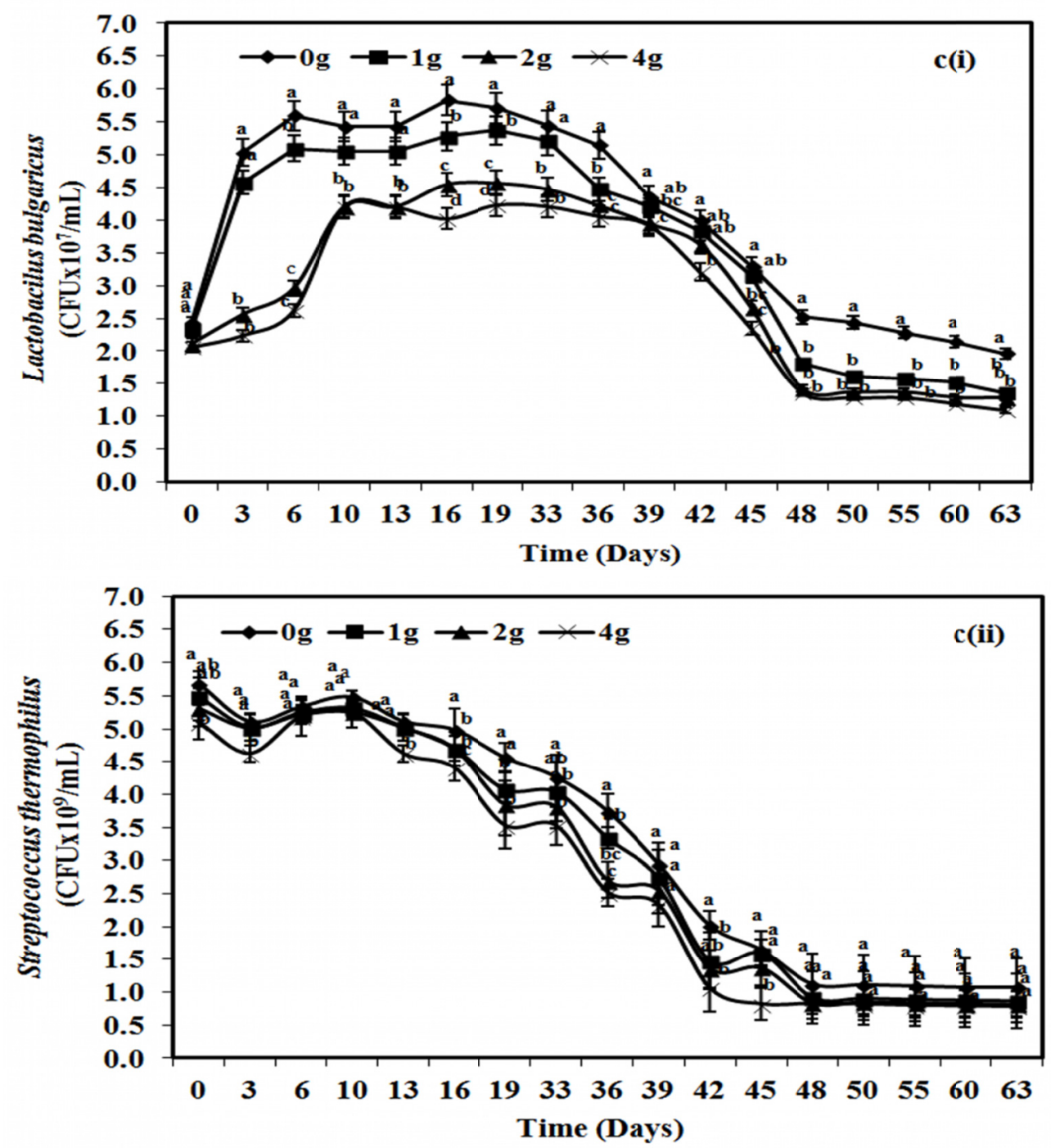

Figure 3c. (i) Lactobacillus bulgaricus (CFU $\left.\times 10^{7} / \mathrm{mL}\right)$ and (ii) Streptococcus thermophilus $\left(\mathrm{CFU} \times 10^{9} / \mathrm{mL}\right)$ in Purple tea fortified yoghurts. Values are Means of three replicates in $1 \mathrm{~mL}$ of sample 


\subsection{Starter Culture at Development Stage}

Lactobacillus bulgaricus in black tea recorded readings of $0.12,1.16$ and $2.86 \times 10^{7} \mathrm{CFU} / \mathrm{mL}$ for $0 \mathrm{~g} / 250 \mathrm{~mL}$, $0.12,0.93$ and $2.44 \times 10^{7} \mathrm{CFU} / \mathrm{mL}$ for $1 \mathrm{~g} / 250 \mathrm{~mL}, 0.11,0.48$ and $1.21 \times 10^{7} \mathrm{CFU} / \mathrm{mL}$ for $2 \mathrm{~g} / 250 \mathrm{~mL}$ and 0.11 , 0.36 and $1.11 \times 10^{7} \mathrm{CFU} / \mathrm{mL}$ for $4 \mathrm{~g} / 250 \mathrm{~mL}$ tea concentration respectively for time 0,4 and $10 \mathrm{hr}$ (Figure 2ai). Green tea recordings were $0.12,1.14$ and $2.06 \times 10^{7} \mathrm{CFU} / \mathrm{mL}$ for $0 \mathrm{~g} / 250 \mathrm{~mL}, 0.11,0.83$ and $1.84 \times 10^{7} \mathrm{CFU} / \mathrm{mL}$ for $1 \mathrm{~g} / 250 \mathrm{~mL}, 0.10,0.69$ and $1.21 \times 10^{7} \mathrm{CFU} / \mathrm{mL}$ for $2 \mathrm{~g} / 250 \mathrm{~mL}$ and $0.10,0.29$ and $1.04 \times 10^{7} \mathrm{CFU} / \mathrm{mL}$ for 4 $\mathrm{g} / 250 \mathrm{~mL}$ tea concentration for time 0,4 and $10 \mathrm{hr}$ (Figure 2bi). Purple tea recordings were $0.12,1.20$ and $2.96 \times$ $10^{7} \mathrm{CFU} / \mathrm{mL}$ for $0 \mathrm{~g} / 250 \mathrm{~mL}, 0.12,0.98$ and $2.56 \times 10^{7} \mathrm{CFU} / \mathrm{mL}$ for $1 \mathrm{~g} / 250 \mathrm{~mL}, 0.11,0.58$ and $1.25 \times 10^{7}$ $\mathrm{CFU} / \mathrm{mL}$ for $2 \mathrm{~g} / 250 \mathrm{~mL}$ and $0.11,0.40$ and $1.15 \times 10^{7} \mathrm{CFU} / \mathrm{mL}$ for $4 \mathrm{~g} / 250 \mathrm{~mL}$ tea concentration for time 0,4 and $10 \mathrm{hr}$ (Figure 2ci).

Black tea fortified yoghurts had Streptococcus thermophilus ranges of $1.03,3.46$ and $5.55 \times 10^{9} \mathrm{CFU} / \mathrm{mL}$ at tea concentration of $0 \mathrm{~g} / 250 \mathrm{~mL} ; 1.04,2.97$ and $5.37 \times 10^{9} \mathrm{CFU} / \mathrm{mL}$ at $1 \mathrm{~g} / 250 \mathrm{~mL} ; 1.03,2.02$ and $5.21 \times 10^{9}$ $\mathrm{CFU} / \mathrm{mL}$ at $2 \mathrm{~g} / 250 \mathrm{~mL}$ and $1.04,1.87$ and $4.94 \times 10^{9} \mathrm{CFU} / \mathrm{mL}$ at $4 \mathrm{~g} / 250 \mathrm{~mL}$ respectively at time 0,4 and $10 \mathrm{hrs}$ (Fig 2aii). Green tea fortified yoghurts recorded values of $1.03,3.41$ and $5.47 \times 10^{9} \mathrm{CFU} / \mathrm{mL}$ at $0 \mathrm{~g} / 250 \mathrm{~mL}, 1.02$, 2.90 and $5.42 \times 10^{9} \mathrm{CFU} / \mathrm{mL}$ at $1 \mathrm{~g} / 250 \mathrm{~mL}, 1.04,1.99$ and $5.17 \times 10^{9} \mathrm{CFU} / \mathrm{mL}$ at $2 \mathrm{~g} / 250 \mathrm{~mL}$ and $1.02,1.75$ and $5.03 \times 10^{9} \mathrm{CFU} / \mathrm{mL}$ at $4 \mathrm{~g} / 250 \mathrm{~mL}$ respectively for time 0,4 and $10 \mathrm{hr}$ (Figure 2bii). Purple tea recorded values of $1.03,3.46$ and $5.74 \times 10^{9} \mathrm{CFU} / \mathrm{mL}$ for $0 \mathrm{~g} / 250 \mathrm{~mL}, 1.02,3.00$ and $5.47 \times 10^{9} \mathrm{CFU} / \mathrm{mL}$ for $1 \mathrm{~g} / 250 \mathrm{~mL}, 1.01,2.11$ and $5.22 \times 10^{9} \mathrm{CFU} / \mathrm{mL}$ for $2 \mathrm{~g} / 250 \mathrm{~mL}$ and $1.03,1.94$ and $5.07 \times 10^{9} \mathrm{CFU} / \mathrm{mL}$ for $4 \mathrm{~g} / 250 \mathrm{~mL}$ respectively for 0 , 4 and $10 \mathrm{hrs}$ (Figure 2cii).

\subsection{Starter Culture at Storage Stage}

The Lactobacillus bulgaricus load were $1.85,5.70$ and $2.40 \times 10^{7} \mathrm{CFU} / \mathrm{mL}$ for $0 \mathrm{~g} / 250 \mathrm{~mL} ; 1.50,4.80$ and 2.38 $\times 10^{7} \mathrm{CFU} / \mathrm{mL}$ for $1 \mathrm{~g} / 250 \mathrm{~mL} ; 1.37,4.40$ and $2.04 \times 10^{7} \mathrm{CFU} / \mathrm{mL}$ for $2 \mathrm{~g} / 250 \mathrm{~mL}$; and $1.06,4.38$ and $1.37 \times 10^{7}$ $\mathrm{CFU} / \mathrm{mL} 4 \mathrm{~g} / 250 \mathrm{~mL}$ respectively for 0,19 and 63 days (Figure 3ai). Green tea readings were 3.21, 5.69 and $2.68 \times 10^{7} \mathrm{CFU} / \mathrm{mL}$ for $0 \mathrm{~g} / 250 \mathrm{~mL} ; 2.08,5.44$ and $1.73 \times 10^{7} \mathrm{CFU} / \mathrm{mL}$ for $1 \mathrm{~g} / 250 \mathrm{~mL} ; 1.56,4.63$ and $1.69 \times 10^{7}$ $\mathrm{CFU} / \mathrm{mL}$ for $2 \mathrm{~g} / 250 \mathrm{~mL}$ and $1.34,4.37$ and $1.50 \times 10^{7} \mathrm{CFU} / \mathrm{mL}$ for $4 \mathrm{~g} / 250 \mathrm{~mL}$ respectively for 0,19 and 63 days (Figure 3bi). Purple tea readings were 2.43, 5.71 and $1.96 \times 10^{7} \mathrm{CFU} / \mathrm{mL}$ for $0 \mathrm{~g} / 250 \mathrm{~mL} ; 2.33,5.37$ and $1.37 \times 10^{7} \mathrm{CFU} / \mathrm{mL}$ for $1 \mathrm{~g} / 250 \mathrm{~mL} ; 2.11,4.57$ and $1.29 \times 10^{7} \mathrm{CFU} / \mathrm{mL}$ for $2 \mathrm{~g} / 250 \mathrm{~mL}$ and $2.06,4.23$ and 1.10 $\times 10^{7} \mathrm{CFU} / \mathrm{mL}$ for $4 \mathrm{~g} / 250 \mathrm{~mL}$ respectively for 0,19 and 63 days (Figure $3 \mathrm{ci}$ ).

The Streptococcus thermophilus culture load for black tea fortified yoghurt was 5.06, 4.45 and $1.30 \times 10^{9}$ $\mathrm{CFU} / \mathrm{mL}$ for $0 \mathrm{~g} / 250 \mathrm{~mL} ; 5.40,4.41$ and $1.16 \times 10^{9} \mathrm{CFU} / \mathrm{mL}$ for $1 \mathrm{~g} / 250 \mathrm{~mL} ; 5.28,3.77$ and $0.84 \times 10^{9} \mathrm{CFU} / \mathrm{mL}$ for $2 \mathrm{~g} / 250 \mathrm{~mL}$ and $4.85,3.53$ and $0.77 \times 10^{9} \mathrm{CFU} / \mathrm{mL}$ for $4 \mathrm{~g} / 250 \mathrm{~mL}$ respectively for 0,19 and 63days (Figure 3aii). Green tea recordings were as follows; $5.48,4.20$ and 1.53 for $0 \mathrm{~g} / 250 \mathrm{~mL}$ for $0 / 250 \mathrm{~mL} ; 5.43,3.96$ and $1.00 \times 10^{9} \mathrm{CFU} / \mathrm{mL}$ for $1 \mathrm{~g} / 250 \mathrm{~mL} ; 5.33,3.12$ and $0.95 \times 10^{9} \mathrm{CFU} / \mathrm{mL}$ for $2 \mathrm{~g} / 250 \mathrm{~mL} ; 5.30,3.07$ and $0.78 \times 10^{9}$ $\mathrm{CFU} / \mathrm{mL}$ for $4 \mathrm{~g} / 250 \mathrm{~mL}$ respectively for 0,19 and 63 days (Figure 3bii). Purple tea fortified yoghurt recorded values of 5.70, 4.57 and $1.08 \times 10^{9} \mathrm{CFU} / \mathrm{mL}$ for $0 \mathrm{~g} / 250 \mathrm{~mL} ; 5.50,4.08$ and $0.87 \times 10^{9} \mathrm{CFU} / \mathrm{mL}$ for $1 \mathrm{~g} / 250 \mathrm{~mL}$; 5.32, 3.85 and $0.81 \times 10^{9} \mathrm{CFU} / \mathrm{mL}$ respectively for $2 \mathrm{~g} / 250 \mathrm{~mL} ; 5.10,3.53$ and $0.87 \times 10^{9} \mathrm{CFU} / \mathrm{mL}$ for $4 \mathrm{~g} / 250$ $\mathrm{mL}$ respectively 0,19 and 63 days (Figure 3 cii).

\subsection{Phytochemical Determination in Tea Fortified Yoghurts}

The developed products of tea fortified yoghurts containing black, green and purple teas at varying tea concentrations were assayed for polyphenol compounds and the results were positive. Black tea fortified yoghurts contained at least an epigallocatechingallate (EGCG) pigmentation while green tea fortified yoghurts contained both Epicatechin (EC) and epigallocatechin (EGC) pigments. Purple tea on the other had contained Epicatechin (EC) and some unidentified pigments which could have been anthocyanins (Figure 4). However the concentration range was below $5 \times 10^{2} \mu \mathrm{gmL}^{-1}$. 


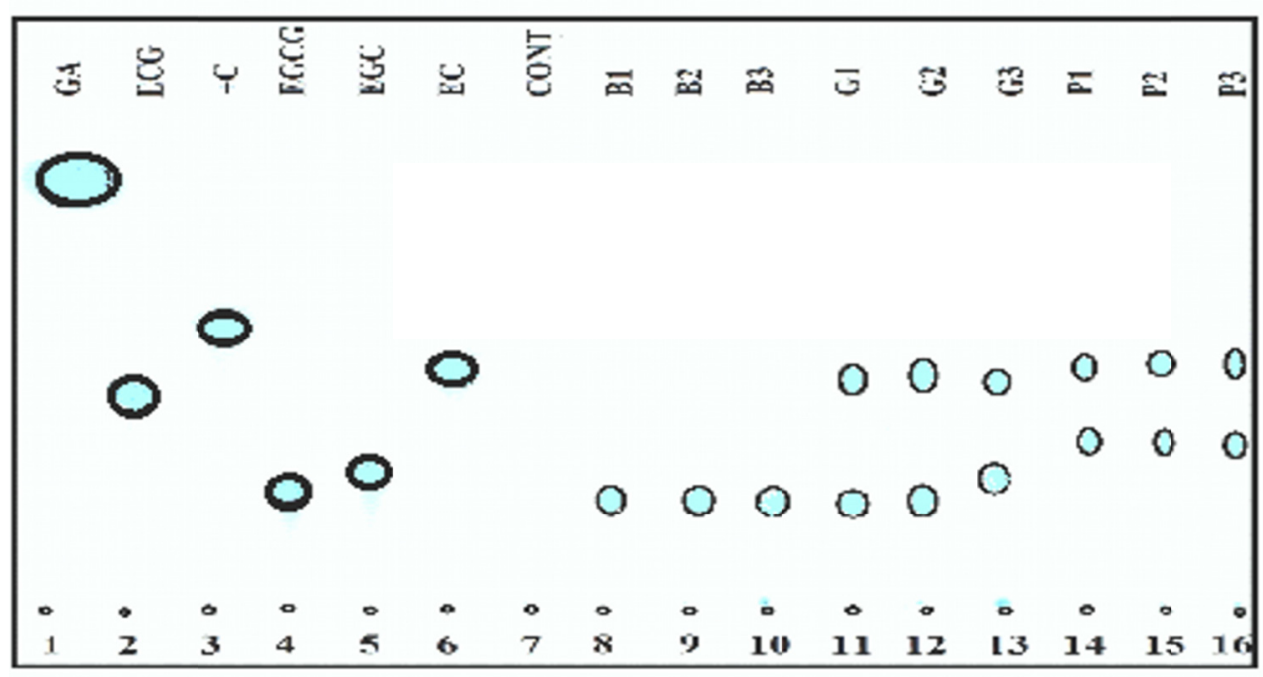

Figure 4. Chromatographs of black, green and purple tea fortified yoghurts at concentrations of $1 \mathrm{~g}, 2 \mathrm{~g}$, and $4 \mathrm{~g} / 250 \mathrm{~mL}$

Track 1 to 6 represents standards. $\mathrm{GA}=$ Gallic acid, $\mathrm{ECG}=$ Epicatechingallate, $+\mathrm{C}=$ Catechin, $\mathrm{EGCG}=$ Epigallocatechingallate, $\mathrm{EGC}=$ Epigallocatechin, $\mathrm{EC}=$ Epicatechin. Tracks 7 to 16 represent samples of black, green and purple tea fortified yoghurts. Small dotes after the track numbers denote the application points of the standards and the samples. Big circles denote the pigment spots separated during sample elution. Track readings were as follows;

$\begin{array}{llll}\text { Track } 1=\mathrm{GA} & \text { Track } 5=\mathrm{EGC} & \text { Track } 9=2 \mathrm{~g} \text { Black } & \text { Track } 13=4 \mathrm{~g} \text { Green } \\ \text { Track } 2=\mathrm{ECG} & \text { Track } 6=\mathrm{EC} & \text { Track } 10=4 \mathrm{~g} \text { Black } & \text { Track } 14=1 \mathrm{~g} \text { Purple } \\ \text { Track } 3=+\mathrm{C} & \text { Track } 7=\text { Control } & \text { Track } 11=1 \mathrm{~g} \text { Green } & \text { Track } 15=2 \mathrm{~g} \text { Purple } \\ \text { Track } 4=\mathrm{EGCG} & \text { Track } 8=1 \mathrm{~g} \text { Black } & \text { Track } 12=2 \mathrm{~g} \text { Green } & \text { Track } 16=4 \mathrm{~g} \text { Purple }\end{array}$

\section{Discussion}

\subsection{Tea Fortified Yoghurts Setting Time}

The different concentrations of $0,1,2$ and $4 \mathrm{~g} / 250 \mathrm{~mL}$ of the tea fortified yoghurts developed from black, green and purple teas recorded different setting times (Table 1). There was a define pattern of significantly $(\mathrm{P} \leq 0.05)$ increased setting time recorded with the increased concentration in tea fortification. There was a mean setting time of $4.11 \mathrm{hr}$ for the controls. The concentration of $1 \mathrm{~g}$ recorded values of 5.10, 5.10 and 5.47hr for black green and purple tea fortification showing that there were no significant differences in setting times of the black and green tea yoghurts at $1 \mathrm{~g} / 250 \mathrm{~mL}$ concentration however there were significant differences with the purple tea fortified yoghurts setting time $(\mathrm{P} \leq 0.05)$ with an average setting time of $5.22 \mathrm{hr}$. Black the concentration at 2 $\mathrm{g} / 250 \mathrm{~mL}$ recorded times of $7.10,7.30$ and $7.47 \mathrm{hr}$ for black, green and purple tea which were significantly different from each other with a mean of $7.29 \mathrm{hr}(\mathrm{P} \leq 0.05)$. At tea concentration of $4 \mathrm{~g} / 250 \mathrm{~mL}$ concentration the recorded times were $8.10,8.33$ and $8.33 \mathrm{hr}$ showing significant differences between the black tea alone and the other two teas green and purple teas $(\mathrm{P} \leq 0.05)$. At each level of concentration black tea had the shortest setting time and purple tea having the longest setting time with green tea recording setting times in between the two. The assay show that addition of tea prolongs setting time of yoghurt as was the case with the addition of hibiscus sabdariffa extract added to yoghurt by Iwalokum and Shittu (Iwalokun \& Shittu, 2007).

\subsection{Starter Culture During Yoghurt Development}

The tea phytochemicals did not inhibit the yoghurt culture upon inoculation into the pasteurized milk fortified with tea. However the incubation and setting times of the tea fortified yoghurts were significantly $(P \leq 0.05)$ prolonged. Enumeration of yoghurt starter culture during tea fortified yoghurt development showed that controls which did not have any added teas had a faster proliferation rate compared to black, green and purple tea fortified yoghurts. This was evident for the two starter cultures lactobacillus bulgaricus and Streptococcus thermophilus (Figure 2ai-ci \& Figure 2aii-cii and Figure 3ai-ci \& Figure 3aii-cii). 
After inoculation the growth of the yoghurt in the teas were as follows; Lactobacillus bulgaricus in black tea fortified yoghurts, $1.53,1.19,0.67$ and $0.57 \times 10^{7} \mathrm{CFU} / \mathrm{mL}$; green tea fortified yoghurt $1.58,0.99,0.70$ and 0.52 $\times 10^{7} \mathrm{CFU} / \mathrm{mL}$; purple tea $1.58,1.26,0.72$ and $0.60 \times 10^{7} \mathrm{CFU} / \mathrm{mL}$ respectively for $0,1,2$ and $4 \mathrm{~g} / 250 \mathrm{~mL}$ concentration in the first $10 \mathrm{hr}$ of yoghurt development. Lactobacillus bulgaricus in black tea had a range of 0.11 $-0.12 \times 10^{7} \mathrm{CFU} / \mathrm{mL}$ for $4 \mathrm{~g}$ and $0 \mathrm{~g}$ for time $0 \mathrm{hr}$ to $1.11-2.8610^{7} \mathrm{CFU} / \mathrm{mL}$ for $4 \mathrm{~g}$ and $0 \mathrm{~g}$ respectively for time $10 \mathrm{hr}$ with a mean of $1.90 \times 10^{7} \mathrm{CFU} / \mathrm{mL}$ showing a suppression effect to the yoghurt culture with increasing addition of tea.. Green tea range was from $0.10-0.12$ for $4 \mathrm{~g}$ and $0 \mathrm{~g} / 250 \mathrm{~mL}$ tea concentration at time $0 \mathrm{hr}$ to $1.04-2.96 \times 10^{7} \mathrm{CFU} / \mathrm{mL}$ for $4 \mathrm{~g}$ and $0 \mathrm{~g} / 250 \mathrm{~mL}$ with a mean of $1.54 \times 10^{7} \mathrm{CFU} / \mathrm{mL}$ Purple tea range was from $0.11-0.12 \times 10^{7} \mathrm{CFU} / \mathrm{mL}$ for $4 \mathrm{~g}$ and $0 \mathrm{~g} / 5 \mathrm{~mL}$ at time $0 \mathrm{hr}$ to 1.15 and $2.96 \times 10^{7} \mathrm{CFU} / \mathrm{mL}$ for $4 \mathrm{~g}$ and $0 \mathrm{~g} / 250 \mathrm{~mL}$ tea concentration with a mean value of 1.98. All the results show indicate a reduction in the starter culture proliferation rate with each addition of tea. However teas did not hinder the growth of starter culture (Figure 2ai-ci).

Streptococcus thermophilus values for black tea fortified yoghurts 3.48, 3.20, 2.74 and $2.53 \times 10^{9} \mathrm{CFU} / \mathrm{mL}$; green tea fortified yoghurts; $3.43,3.16,2.67$ and $2.50 \times 10^{9} \mathrm{CFU} / \mathrm{mL}$; purple tea fortified yoghurts $3.51,3.24$, 2.79 and $2.62 \times 10^{9} \mathrm{CFU} / \mathrm{mL}$ respectively for $0,1,2$ and $4 \mathrm{~g} / 250 \mathrm{~mL}$ for the first $10 \mathrm{hr}$ of development. Streptococcus thermophilus growth patterns in the presence of tea also exhibited suppression with each addition of tea. Black tea fortified yoghurt range was $1.03-1.04 \times 10^{9} \mathrm{CFU} / \mathrm{mL}$ for $0-4 \mathrm{~g} / 250 \mathrm{~mL}$ for time $0 \mathrm{hr}$ to values of 4.92-5.55 $\times 10^{9} \mathrm{CFU} / \mathrm{mL} 4-0 \mathrm{~g} / 250$ concentration of tea. Green tea range was $1.02-1.03$ for $0 \mathrm{~g}$ and $4 \mathrm{~g} / 250 \mathrm{~mL}$ at time $0 \mathrm{hr}$ to $5.03-5.47 \times 10^{9} \mathrm{CFU} / \mathrm{mL}$ at time $10 \mathrm{hr}$ for $4 \mathrm{~g}$ and $0 \mathrm{~g} / 250 \mathrm{mzL}$ respectively. Purple tea had an initial mean of $1.03 \times 10^{9} \mathrm{CFU} / \mathrm{mL}$ for $4 \mathrm{~g}$ and $0 \mathrm{~g} / 250 \mathrm{~mL}$ concentration to $5.07-5.47 \times 10^{9} \mathrm{CFU} / \mathrm{mL}$ for $4 \mathrm{~g}$ and $0 \mathrm{~g} / 25$ $\mathrm{mL}$ respectively. However the acceptable level (Sera et al., 2009) for the starter culture load was met at the end of the development period of $10 \mathrm{hr}$ (Figure 2aii-cii).

\subsection{Starter Culture at Storage}

The critical quantities of the cultures that is $10^{6}-10^{8} \mathrm{CFU} / \mathrm{mL}$ for Lactobacillus bulgaricus and Streptococcus thermophilus was achieved and surpassed by $10^{1}$ and $10^{2} \mathrm{CFU} / \mathrm{mL}$ respectively (Figure 2 a-c and 3a-c) from production date during storage and at the end of the storage period of 63 days. Usually yoghurt has a shelf life of 45 days.

During yoghurt storage the growth patterns were different with Lactobacillus bulgaricus on a low at day 0 to a maximum at day 19 to a decline to a low rate at day 45 and a final lowest peak at day 63 . The recorded proliferation rates for the different tea fortified yoghurts were as follows: Black tea fortified yoghurts 3.86, 3.47, 3.25 and $2.79 \times 10^{7} \mathrm{CFU} / \mathrm{mL}$ Green tea fortified yoghurts $4.35,3.77,3.28$ and $3.07 \times 10^{7} \mathrm{CFU} / \mathrm{mL}$ and purple tea fortified yoghurts, 4.06, 3.62, 2.99 and $2.80 \times 10^{7} \mathrm{CFU} / \mathrm{mL}$ for $0,1,2$ and $4 \mathrm{~g} / 250 \mathrm{~mL}$ milk concentration. However the counts remained within the accepted range of $10^{6}$ and $10^{8} \mathrm{CFU} / \mathrm{mL}$ (Serra, Trujillo, Guamis, \& Ferragut, 2009). The shelf life for yoghurts is usually set at 45 days which as seen from the graphs is a time period at which optimum counts of the Lactobacillus bulgaricus can be obtained. Black, green and purple tea fortified yoghurts displayed a similar trend. There were significant differences in the microbial counts of controls and that of all the added teas from concentrations 2 and $4 \mathrm{~g} / 250 \mathrm{~mL}(\mathrm{P} \leq 0.05)$. On the other had no significant differences were recorded between tea fortification at $0 \mathrm{~g} / 250 \mathrm{~mL}$ and $1 \mathrm{~g} / 250 \mathrm{~mL}$ tea concentration in all the tea fortified yoghurt. Although the differences in the microbial load of Lactobacillus bulgaricus in the various tea fortified yoghurts and different concentrations was significant $(\mathrm{P} \leq 0.05)$, the counts were still within the accepted range of $10^{6}$ and $10^{8} \mathrm{CFU} / \mathrm{mL}$ (Figure 3ai-ci) as recommended for yoghurts (Serra, Trujillo, Guamis, \& Ferragut, 2009)

Streptococcus thermophilus growth pattern was slightly different starting from a maximum at day 0 to a slight decline at day 19 to a steep decline to day 45 with slight stagnation to a final low decline to day 63 . Means of proliferation rates were as follow: black tea fortified yoghurts 3.37, 3.18, 2.92 and $2.67 \times 10^{9} \mathrm{CFU} / \mathrm{mL}$; green tea fortified yoghurts $3.47,3.11,2.84$ and $2.57 \times 10^{9} \mathrm{CFU} / \mathrm{mL}$ and purple tea fortified yoghurts 3.32, 3.09, 2.96 and $2.76 \times 10^{9} \mathrm{CFU} / \mathrm{mL}$ for $0,1,2$ and $4 \mathrm{~g} / 250 \mathrm{~mL}$ tea concentration. The microbial load for Streptococcus thermophilus was highest in the first 18days and then declined progressively from day 19 to day 45 and then slowly started stagnating with slight decline from day 45 onwards to day 63 of storage. The shelf life of yoghurt at 45 days could also have been informed by this trend observed in the tea fortified yoghurt development since optical culture load are obtained from day 1 to day 45 of storage. However, acceptable microbial load still persisted to day 63 (Figure 3aii-cii), where our studies ended and the microbial load of Streptococcus thermophilus was still within the recommended range of $10^{6}$ and $10^{8} \mathrm{CFU} / \mathrm{mL}$ (Fadela, Abderrahim, \& Ahmed, 2009; Serra et al., 2009). 


\subsection{Phytochemical Determination in Tea Fortified Yoghurts}

The assay showed that all the tea fortified yoghurts contained individual phytochemicals that impart health benefits to the teas. The three different tea fortified yoghurts contained different active components. Black tea fortified yoghurts had traces of EGCG, green tea had traces of EGC and EC while purple tea fortified yoghurts had traces of anthocyanin pigments. All these showed that the developed tea fortified yoghurts also possessed teas health benefits as has been found in other tea fortified foods (Jaziri et al., 2005; Yilmaz, 2006).

\section{Conclusion}

Tea phytochemicals did not adversely affect the growth and survival of yoghurt starter culture, despite its antimicrobial activity. Setting time was however, prolonged. As the concentration of tea was increased setting time was also increased, with normal setting time for non-fortified yoghurt, being recorded when the $\mathrm{pH}$ is between 4.5 and 4.7. Black tea fortified yoghurt had the least setting time while purple fortified yoghurt had the longest setting time at each level of fortification. This time factor needs to be taken into consideration during the processing of these tea fortified yoghurt since it is longer than those of the ordinary yoghurts.

Microbial proliferation and growth pattern was maintained in all the tea fortified yoghurts with respect to the various tea concentrations. Microbial growth was high at low concentration of $0 \mathrm{~g} / 250 \mathrm{~mL}$ milk and lowest at concentrations of $4 \mathrm{~g} / 250 \mathrm{~mL}$ milk.

Storage stability studies regarding the survival rate of the cultures showed that during the entire storage period, all the tea fortified yoghurts were able to sustain the required starter microbial load at the various levels of tea fortification up to the last experimental day. The microbial load studies lasted 63 days while the average shelf life of yoghurt at retail stores is usually 45 days. The studies revealed that the shelf life of the commercial yoghurt products were set at optimum ranges from day 1 to day 45 although there is still plenty of nutritive value within acceptable ranges of $10^{6}-10^{8} \mathrm{CFU} / \mathrm{mL}$ of microbial load if consumption is continued for 63 days.

The production of the tea fortified yoghurt rich in tea phytochemicals is achievable. These development will increase tea consumption and subsequently increase revenue to tea growers and tea growing regions.

\section{Acknowledgments}

The authors sincerely thank Kenya Agricultural and Livestock Research Organization (KALRO)-Tea Research Institute (TRI) and National Commission for Science, Technology and Innovation (NACOSTI) for funding the project.

\section{References}

Almajano, M. P., Carbó, R., Jiménez, J. A. L., \& Gordon, M. H. (2008). Antioxidant and antimicrobial activities of tea infusions. Food Chemistry, 108(1), 55-63. http://dx.doi.org/10.1016/j.foodchem.2007.10.040

Arakawa, H., Maeda, M., Okubo, S., \& Shimamura, T. (2004). Role of Hydrogen Peroxide in Bactericidal Action of Catechin. Biological \& Pharmaceutical Bulletin, 27(3), 277-281. http://dx.doi.org/10.1248/bpb.27.277

Balentine, D. A. (1997). Introduction; Tea and health. Food Science Nutrition, 8, 691-669.

Campbell, R. W. (2003). Dairy Products and Nutritional Performance in the Diets of People with HIV / AIDS, An Informational Monograph from Land O'Lakes International Development Division.

Cheruiyot, E. K., Mumera, L. M., Ng'etich, W. K., Hassanali, A., \& Wachira, F. (2007). Polyphenols as potential indicators for drought tolerance in tea (Camellia sinensis L.). Bioscience, Biotechnology, and Biochemistry, 71(9), 2190-7. http://dx.doi.org/10.1271/bbb.70156

Chosa, H., Toda, M., Okubo, S., Hara, Y., \& Shimamura, T. (1992). Antimicrobial and microbicidal activities of tea and catechins against Mycoplasma. Journal of the Japanese Association for Infectious Diseases, 66, 606-611. http://dx.doi.org/10.11150/kansenshogakuzasshi1970.66.606

Cisowska, A., Wojnicz, D., \& Hendrich, A. B. (2011). Anthocyanins as antimicrobial agents of natural plant origin. Natural Product Communications, 6(1), 149-156.

Fadela, C., Abderrahim, C., \& Ahmed, B. (2009). Sensorial and physico-chemical characteristics of yoghurt manufactured with ewe's and skim milk. World Journal of Dairy \& Food Sciences, 4(2), 136-140.

Fassina, G., Buffa, A., Benelli, R., Varnier, O. E., Noonan, D. M., \& Albini, A. (2002). Polyphenolic antioxidant (-)-epigallocatechin-3-gallate from green tea as a candidate anti-HIV agent. AIDS (London, England), 16(6), 939-41. http://dx.doi.org/10.1097/00002030-200204120-00020

Goto, K., Kanaya, S., Nishikawa, T., Hara, H., Terada, A., Ishigami, T., \& Hara, Y. (1998). The influence of tea 
catechins on fecal flora of elderly residents in long-term care facilities. Ann Long-Term Care, 6, 43-48.

Hamilton-Miller, J. M. (2001). Anti-cariogenic properties of tea (Camellia sinensis). Journal of Medical Microbiology, 50(4), 299-302.

Hamilton-Miller, J. M., \& Shah, S. (1999). Disorganization of cell division of methicillin-resistant Staphylococcus aureus by a component of tea (Camellia sinensis): A study by electron microscopy. FEMS Microbiology Letters, 176(2), 463-469. http://dx.doi.org/10.1111/j.1574-6968.1999.tb13698.x

Hara, Y. (2001). Green Tea--Health Benefits and Applications. Am J Clin Nutr (Vol. 77). New York, USA: Marcel Dekker. http://dx.doi.org/10.1201/9780203907993

Hara, Y., Luo, S. J., Wickremashinghe, R. L., \& Yamanishi, T. (1995). Botany of tea. Food Revised International, $11,371-374$.

Hirasawa, M., \& Takada, K. (2004). Multiple effects of green tea catechin on the antifungal activity of antimycotics against Candida albicans. Journal of Antimicrobial Chemotherapy, 53(2), 225-229. http://dx.doi.org/10.1093/jac/dkh046

Hsu, S. (2005). Green tea and the skin. Journal of the American Academy of Dermatology, 52(6), 1049-1059. http://dx.doi.org/10.1016/j.jaad.2004.12.044

Ikigai, H., Nakae, T., Hara, Y., \& Shimamura, T. (1993). Bactericidal catechins damage the lipid bilayer. $\begin{array}{lllll}\text { Biochimica et Biophysica Acta (BBA)-Biomembranes, } & 1147(1), & 132-136 .\end{array}$ http://dx.doi.org/10.1016/0005-2736(93)90323-R

Iwalokun, B. A., \& Shittu, M. O. (2007). Effect of Hibiscus sabdariffa (calyce) extract on biochemical and organoleptic properties of yogurt. Pakistan Journal of Nutrition, 6(2), 172-182. http://dx.doi.org/10.3923/pjn.2007.172.182

Jaziri, I., Slama, M. Ben, Mhadhbi, H., Gannoun, H., \& Othman, N. B. (2005). Preparation of yoghurts with tea by preserving nutritional qualities of yoghurt and adding tea benefits on human health. Tunisia.

Jaziri, I., Slama, M. Ben, Mhadhbi, H., Urdaci, M. C., \& Hamdi, M. (2009). Effect of green and black teas (Camellia sinensis L.) on the characteristic microflora of yogurt during fermentation and refrigerated storage. Food Chemistry, 112(3), 614-620. http://dx.doi.org/10.1016/j.foodchem.2008.06.017

Karori, S. M., Wachira, F. N., Wanyoko, J. K., \& Ngure, R. M. (2007). Antioxidant capacity of different types of tea products. African Journal of Biotechnology, 6(19).

Kerio, L. C., Wachira, F. N., Wanyoko, J. K., \& Rotich, M. K. (2013). Total polyphenols, catechin profiles and antioxidant activity of tea products from purple leaf coloured tea cultivars. Food Chemistry, 136(3-4), 1405-13. http://dx.doi.org/10.1016/j.foodchem.2012.09.066

Kilel, E. C., Faraj, A. K., Wanyoko, J. K., Wachira, F. N., \& Mwingirwa, V. (2013). Green tea from purple leaf coloured tea clones in Kenya- their quality characteristics. Food Chemistry, 141(2), 769-75. http://dx.doi.org/10.1016/j.foodchem.2013.03.051

Koech, K. R., Wachira, F. N., Ngure, R. M., Wanyoko, J. K., Bii, C. C., Karori, S. M., \& Kerio, L. C. (2013). Antimicrobial, synergistic and antioxidant activities of tea polyphenols. In A. Mendez-Vilas (Ed.), Microbial pathogens and strategies for combating them (pp. 971-981).

Koech, R. K., Wanyoko, J., \& Wachira, F. (2014). Antioxidant, antimicrobial and synergistic activities of tea $\begin{array}{llllll}\text { polyphenols. International Journal of Infectious Diseases, } & 21, & 98 .\end{array}$ http://dx.doi.org/10.1016/j.ijid.2014.03.631

Lelgo, S. K., Kamunya, S. M., Ochanda, S. O., \& Wanyoko, J. K. (2011). The effect of processing technique on biochemical composition of adapted Kenyan and introduced Japanese and Chinese Tea germplasm. Tea, 32(1), 22-23.

Marth, E. H., \& Steele, J. L. (2001). Applied dairy Microbiology. In M. Dekker (Ed.), Technology and Induswtrial Arts (2nd ed., p. 744).

Mukhtar, H., \& Ahmad, N. (2000). Tea polyphenols: prevention of cancer and optimizing health. Am J Clin Nutr, 71(6), 1698S-1702.

Navarro-Martínez, M. D., Navarro-Perán, E., Cabezas-Herrera, J., Ruiz-Gómez, J., García-Cánovas, F., \& Rodríguez-López, J. N. (2005). Antifolate activity of epigallocatechin gallate against Stenotrophomonas maltophilia. Antimicrobial Agents and Chemotherapy, 49(7), 2914-2920. 
http://dx.doi.org/10.1128/AAC.49.7.2914-2920.2005

Ochanda, S. O. (2010). A Review on Tea Manufacture, Tea types and Tea products in the Kenyan Tea Industry. Tea Journal, 31(1), 38-48.

Ochanda, S. O., Wanyoko, J. K., Onyango, C. A., Faraj, A. K., \& Kamunya, S. M. (2012). Screening of suitable clones for Un-aerated tea production. African Journal of Horticultural Science.

Oh, J., Jo, H., Cho, A. R., Kim, S. J., \& Han, J. (2013). Antioxidant and antimicrobial activities of various leafy herbal teas. Food Control, 31(2), 403-409. http://dx.doi.org/10.1016/j.foodcont.2012.10.021

Okubo, S., Toda, M., Hara, Y., \& Shimamura, T. (1991). Antifungal and fungicidal activities of tea extract and catechin against Trichophyton. Nihon Saikingaku Zasshi. Japanese Journal of Bacteriology, 46(2), 509-14. http://dx.doi.org/10.3412/jsb.46.509

Paveto, C., Güida, M. C., Esteva, M. I., Martino, V., Coussio, J., Flawiá, M. M., \& Torres, H. N. (2004). Anti-Trypanosoma cruzi activity of green tea (Camellia sinensis) catechins. Antimicrobial Agents and Chemotherapy, 48(1), 69-74. http://dx.doi.org/10.1128/AAC.48.1.69-74.2004

Prior, R. L., \& Wu, X. (2006). Anthocyanins: Structural characteristics that result in unique metabolic patterns and biological activities. Free Radical Research, 40(10), 1014-1028. http://dx.doi.org/10.1080/10715760600758522

Rao, M. B., Tanksale, A. M., Ghatge, M. S., \& Deshpande, V. V. (1998). Molecular and biotechnological aspects of microbial proteases. Microbiology and Molecular Biology Reviews, 62(3), 597-635.

Robertson, A. (1992). The chemistry and biochemistry of black tea production, the non volatiles. In K. C. Wilson \& M. N. Clifford (Eds.), Tea: Cultivation to consumption (pp. 555-601). UK London: Chapman and Hall. http://dx.doi.org/10.1007/978-94-011-2326-6_17

Roseboom, J., \& Pardey, P. G. (1993). Statistical brief on the national agricultural research system of Kenya. ISNAR.

Serra, M., Trujillo, A. J., Guamis, B., \& Ferragut, V. (2009). Flavour profiles and survival of starter cultures of yoghurt produced from high-pressure homogenized milk. International Dairy Journal, 19(2), 100-106. http://dx.doi.org/10.1016/j.idairyj.2008.08.002

Sharquie, K. E., Al-Turfi, I. A., \& Al-Salloum, S. M. (2000). The antibacterial activity of tea in vitro and in vivo (in patients with impetigo contagiosa). The Journal of Dermatology, 27(11), 706-10. http://dx.doi.org/10.1111/j.1346-8138.2000.tb02263.x

Song, J.-M., Lee, K.-H., \& Seong, B.-L. (2005). Antiviral effect of catechins in green tea on influenza virus. Antiviral Research, 68(2), 66-74. http://dx.doi.org/10.1016/j.antiviral.2005.06.010

Stapleton, P. D., Shah, S., Anderson, J. C., Hara, Y., Hamilton-Miller, J. M. T., \& Taylor, P. W. (2004). Modulation of $\beta$-lactam resistance in Staphylococcus aureus by catechins and gallates. International Journal of Antimicrobial Agents, 23(5), 462-467. http://dx.doi.org/10.1016/j.ijantimicag.2003.09.027

Stapleton, P. D., Shah, S., Hamilton-Miller, J. M. T., Hara, Y., Nagaoka, Y., Kumagai, A., ... Taylor, P. W. (2004). Anti-Staphylococcus aureus activity and oxacillin resistance modulating capacity of 3-O-acyl-catechins. International Journal of Antimicrobial Agents, 24(4), 374-380. http://dx.doi.org/10.1016/j.ijantimicag.2004.03.024

Trienekens, J. H. (2011). Agricultural value chains in developing countries a framework for analysis. International Food and Agribusiness Management Review, 14(2).

Varga, L. (2006). Effect of acacia (Robinia pseudo-acacia L.) honey on the characteristic microflora of yogurt during refrigerated storage. International Journal of Food Microbiology, 108(2), 272-5. http://dx.doi.org/10.1016/j.ijfoodmicro.2005.11.014

Walsh, J. A. (1969). Book Reviews : George W. Snedecor and William G. Cochran. Statistical Methods. (6th ed.) Ames, Iowa: The Iowa State University Press, 1967. Pp. xiv + 593. Educational and Psychological Measurement, 29(2), 546-549. http://dx.doi.org/10.1177/001316446902900247

Wilson, K. C., \& Clifford, M. N. (1991). Tea: Cultivation to consumption.

Yilmaz, Y. (2006). Novel uses of catechins in foods. Trends in Food Science \& Technology, 17(2), 64-71. http://dx.doi.org/10.1016/j.tifs.2005.10.005

Zhang, Y.-M., \& Rock, C. O. (2004). Evaluation of epigallocatechin gallate and related plant polyphenols as 
inhibitors of the FabG and FabI reductases of bacterial type II fatty-acid synthase. Journal of Biological Chemistry, 279(30), 30994-31001. http://dx.doi.org/10.1074/jbc.M403697200

\section{Copyrights}

Copyright for this article is retained by the author(s), with first publication rights granted to the journal.

This is an open-access article distributed under the terms and conditions of the Creative Commons Attribution license (http://creativecommons.org/licenses/by/3.0/). 